\title{
Implementing Authentic Assessment in the 2013 Curriculum by English Teachers of Modern Boarding High School
}

\author{
Diki Atmarizon ${ }^{1}$, Novita Efendi ${ }^{2}$, Sherly Franchisca ${ }^{3}$ \\ 1 Universitas Nahdlatul Ulama Sumatra Barat, Indonesia \\ ${ }^{2}$ Senior High School Prof. Dr. Hamka Padang, Indonesia \\ 3 Universitas Ekasakti Padang, Indonesia
}

Corresponding Author: Diki Atmarizon, dikiatmarizon@gmail.com*

\begin{tabular}{|c|c|}
\hline \multirow{3}{*}{$\begin{array}{c}\text { ARTICLE INFO } \\
\text { Article history: } \\
\text { Received } \\
\text { November 25, } 2019 \\
\text { Revised } \\
\text { April 30, 2020 } \\
\text { Accepted } \\
\text { May 28, } 2020\end{array}$} & ABSTRACT \\
\hline & $\begin{array}{l}\text { This article aimed to express the implementing authentic assessment in } \\
\text { the } 2013 \text { curriculum by English teachers of Prof. Dr. Hamka Padang } \\
\text { Modern Boarding High School. The illustration enclosed the kinds of } \\
\text { authentic assessment, the implementation and the problems } \\
\text { encountered by the English teachers. The subjects were two English } \\
\text { teachers and } 36 \text { students. Observation checklist, questionnaire sheet and } \\
\text { interview guideline were used as the research instruments. This is } \\
\text { descriptive research and analyzed by qualitatively. The results showed } \\
\text { that kinds of authentic assessment implemented by the two English } \\
\text { teachers were oral interview, observation, writing sample, project, } \\
\text { constructed-respond item and performance by score } 45,55 \% \text { with "poor } \\
\text { category". Although they have maximized their effort, they did not do } \\
\text { better on the preparing, scoring, and reporting. Then, lack of time, } \\
\text { knowledge and difficult to find appropriate material were still being } \\
\text { problems encountered by the English teachers in implementing of the } \\
\text { authentic assessment. }\end{array}$ \\
\hline & Keywords: Authentic Assessment, Curriculum 2013, English Teachers \\
\hline How to cite & $\begin{array}{l}\text { Atmarizon, D., Efendi, N., \& Franchisca, S. (2020). Implementing Authentic } \\
\text { Assessment in the } 2013 \text { Curriculum by English Teachers of Modern Boarding } \\
\text { High School. Jurnal Iqra': Kajian Ilmu Pendidikan, 5(1). 26-42. } \\
\text { https://doi.org/10.25217/ji.v5i1.617 }\end{array}$ \\
\hline Journal Homepage & http://journal.iaimnumetrolampung.ac.id/index.php/ji/ \\
\hline $\begin{array}{l}\text { This is an open access } \\
\text { Published by }\end{array}$ & $\begin{array}{l}\text { ticle under the CC BY SA license } \\
\text { https:// creativecommons.org/licenses/by-sa/4.0/ } \\
\text { Institut Agama Islam Ma'arif NU (IAIMNU) Metro Lampung }\end{array}$ \\
\hline
\end{tabular}

\section{INTRODUCTION}

The 2013 curriculum requires the students to actively participate in learning. They have to be more creative, innovative, and productive. Meanwhile, the teachers are required professionally to design, organize, choose effective and meaningful activities in learning process, and determine the achievements criteria for their students (Setiadi, 2016; Haslina, 2017). The teachers are also required to monitor their students' progress on the learning process, and one of the ways is by using assessments. Authentic assessment displays the implementation of students' certain skills and judgment and dwells more on problem-solving, comprehension, critical thinking, reasoning, and metacognition (Kinay \& Bagceci, 2016). It serves as assistance for teachers in 
deploying the students into certain groups, improving teaching method and providing guidance (Retnawati et al., 2016).

According to Standar Penilaian Pendidikan (2013), about standard of assessment stated that assessment in primary and secondary schools was conducted by teachers, schools, government and/or independent institution. A very effective pathway for both the teachers and the students to look for and to get the desirable results was assessment rubric (Azim \& Khan, 2012). In line with it, implementation of assessment instruments affects the learning outcomes (Damayanti et al., 2017). Teachers had to assess their students completely related to the students' knowledge, skill, and attitude aspect during the learning process. It is supported by Kurniasih who argued that authentic assessment is an assessment held comprehensively to rate input, process and output of the learning related to students' knowledge, attitude, and skill (Kurinasih, 2014).

2013 Curriculum has been applied in every school in Indonesia, but it is still found that many teachers have implemented it unsuccessfully (Maba \& Mantra, 2018). Preliminary research was done to English teachers of Prof. Dr. Hamka Padang Modern Boarding High School by interviewing informally. There were still found difficulties on implementing the authentic assessment. Their responsibility did not only give score or checklist on the students' activities on the instrument sheet of the authentic assessment, but it also provided some feedbacks in the form of comments or written description on the students' knowledge, skill, and attitude. It the same as Widodawati's reports, every aspect of students' scientific thinking skills has been improved by providing feedback on students' knowledge, skill dan attitude (Widowati et al., 2017). Moreover, it is also believed that the administration of appropriate testing can create supporting classroom learning environment (Arigusman, 2017).

English teachers can implement some assessments in the teaching English in the forms written or oral test, observation, self-assessment, attitude measurement, and assessment of a task, project, and portfolios. In 2013 English Curriculum, those assessment are used to measure the competence; attitude, knowledge and, skill as follow: First, observation, self-assessment, peer-evaluation and journal are used to assess the attitude (Zulela, M. S., \& Marini, A, 2019 ;Kunandar, 2013). Second, written or oral test and task assignment such as homework, individual or group project are used to assess the knowledge. Third, assessment of skill can be assessed through performance test, project and portfolio. The assessment of skill is to measure students' achievement which consist of several aspects such as imitation, manipulation, precision, articulation and naturalization. Martinez Lirola \& Irwin (2016) claimed that when the learners are able to understand the contextual constraints of a specific text type and its path to accomplishing its objective, they are able to write effectively. Especially in assessments of Portfolio are believed to be more authentic and objective in evaluating the students' performance (Fauziah et al., 2017). In line with it, Portfolio is seemingly quite possibly the most popular form of authentic assessment. An 
intrinsic part of ongoing class work, the portfolio arises from the context of daily life (Adeyemi, 2015). The real condition shows that some teachers are not familiar enough with some techniques in authentic assessment in teaching English such as self-peer assessment, project based assessment and portfolio (Öz, 2014).

Meanwhile, 2013 English Curriculum used assessment such as written or oral test, task-assignment, individual or group project, performance test, project, portfolio, observation, self-assessment, peer-evaluation, and journal (Standar Penilaian Pendidikan, 2013). Mueller (2017) asserted that the process of authentic assessment based on the 2013 English Curriculum. It was also implemented by Adeyemi (2015) who explained that the assessment process begins by reviewing the syllabus as a guideline in drafting and designing criteria of assessment at the starting of the semester. The Implementation of the assessment in the studying activity is begun by investigating and ended with a test and/or non-test. Assessment on integrated-thematic learning is conducted by referencing to indicators of basic competencies each subject that is integrated into the theme. Results of the assessment are analyzed by teachers to determine progress and learning difficulties.

Concerning researches in implementing authentic assessment in 2013 Curriculum, there were several previous researches have been done in different setting which showed the 2013 implementation in schools. First, (Lestari, 2010) did the research entitled A Survey on the Implementation of Authentic Assessment in Public Junior High School in Malang Municipalit. The finding of this study shows that the English teachers of public junior high school in Malang were still lack of knowledge about authentic assessment. In the implementation, the teachers have no enough preparation in the preparation stage. Consequently the implementation of authentic assessment did not go without a hitch. The second conducted by Pemila (2014) entitled The Implementation of Authentic Assessment in Teaching Bahasa Indonesia for Senior High Schools Based on 2013 Curriculum in Gunung Kidul District. The result showed that the teachers couldn't be able to maximize the implementation of authentic assessment yet. The teachers have conducted authentic assessment and follow the stages they need to take. Nevertheless, the teachers didn't implement the assessment maximally yet, especially in designing the rubric and scoring. Since several researchers above had the same analysis about authentic assessment in language studies, more studies needed to be conducted whether the authentic assessment had been implemented well in schools in Indonesia especially in 2013 Curriculum which emphasizes the implementation of authentic assessment.

Based on the previous studies above, it was implied that the English teachers still need implement an authentic assessment in teaching English by conducting systematic procedures which are begun with preparing, implementing, scoring, and reporting. Considering this problem, the teachers should be based on the procedures by (Standar Penilaian Pendidikan, 2013), detail involve begins the steps of assessment by reviewing the syllabus as a 
guideline in creating lesson plan and designing assessment criteria. After that, teachers select appropriate assessment and develop the instruments and scoring guidelines in accordance with the types chosen; 2. Implementation: (Kemendikbud, 2014) emphasizes that the teacher begins the lesson by exploring students' learning experience. The teachers ask some questions which consider the condition and level of the students; 3. Scoring; The results of learning are analyzed by teachers to determine progress and learning difficulties. It is used to score students' performances in order to stimulate them to learn (Rukmini, D., \& Saputri, 2017; Idham, F. I., Nadrun, 2015). After that, the results are reverted feedback to the students in the review form that courage them in learning; 4. Reporting: After documenting the result by using rating scale, checklist, or anecdotal records, the data collected in authentic assessment is analyzed as the report to students, parent, or other teachers in the school.

The theories above gave clear enlightenment how the English teachers could implement the authentic assessment in teaching English through systematic implementation. In accordance with up line discussion, there were any previous studies have been conducted in diverse situation which implemented authentic assessment. First, Lestari (2010) deal with Implementation of Authentic Assessment in Public Junior High School in Malang. Second, Pemila (2014) concerned with The Implementation of Authentic Assessment in Teaching Bahasa Indonesia for Senior High Schools Based on 2013 Curriculum. Thus, it was absorbed to carry out a research in Prof. Dr. Hamka Padang Modern Boarding High School with supposed to obtain extent proof on the implementing authentic assessment in 2013 curriculum. The features to be revolved were to find out the kinds of authentic assessment which were implemented by the English teachers, how they implement it, problems were encountered by them.

\section{METHODS}

This research was classified into a descriptive - qualitative research aiming at gain information about phenomenon in order to describe the existing condition in the field (Moser \& Korstjens, 2018; Merriam \& Grenier, 2019). As the key instrument in this research, the researcher actively observed 2 teachers and 36 students, interviewed 2 teachers and collected various data. The interview was conducted for the two English teachers who teach at Prof. Dr. Hamka Padang Modern Boarding High School in X grade. The teachers were interviewed one by one by using the interview guideline, and all the conversation during the interview was recorded. The interview was foscused on the problems using authentic assessment at Prof. Dr. Hamka Padang Modern Boarding High School which was one of new modern schools in West Sumatera. The interview results were transcript into description to support the data from observation and questionnaire. The population was two English teachers as well as 36 students who studied at the $\mathrm{X}$ grade at Prof. Dr. Hamka Padang Modern Boarding High School so all teachers and students for two classes were selected as the subject of this research. 
The observation checklist sheet was designed to see the kinds of implementing authentic assessment by the teachers in teaching English. The source could be in form of teachers' instrument. Observation checklist sheet included several types of authentic assessment. Each type of authentic assessment was followed by the descriptions to prevent ambiguity in giving the checklist to the document. The researcher observed the implementing Authentic Assessment by the teachers using observation checklist sheet, and gave a checklist in 'Yes' column for the available source, and checklist in 'No' column if there was no document found. The questionnaire were administered to the two English teachers and the 36 students at Prof. Dr. Hamka Padang Modern Boarding High School related to the implementation each types of authentic assessment by the teachers. Each teacher was directed how to fill in the questionnaire after teaching and learning process even it was also for students.

The data which were obtained from observation checklist, questionnaire, and interview were analyzed descriptively by using qualitative method. The observation checklist and questionnaire were analyzed quantitatively to measure the level of achievement of implementing authentic assessment. The quantitative data were measured by using the formulation as described below:

Table 1. Assessment Criteria

\begin{tabular}{l} 
Table 1. Assessment Criteria \\
\begin{tabular}{|c|c|}
\hline Criteria & Percentage \\
\hline Very Good & $>90$ \\
\hline Good & $71-90$ \\
\hline Fair & $51-70$ \\
\hline Poor & $31-50$ \\
\hline Very Poor & $<31$ \\
\hline $\mathrm{Pi}=\mathrm{F} / \mathrm{N} \times 100 \% ;$ \\
$\mathrm{Pi}:$ Percentage of Analysis \\
$\mathrm{F}:$ Frequency appeared \\
$\mathrm{N}:$ Number of indicators analyzed
\end{tabular} \\
\hline
\end{tabular}

In order to determine the achievement criteria of authentic assessment implementation, it was used Likert scale by (Yusuf, 2017). He divided the assessment criteria into five categories: very good, good, fair, poor, and very poor

\section{RESULT AND DISCUSSION}

Build upon the data, there were two English teachers implemented the authentic assessment in 2013 curriculum at Prof. Dr. Hamka Padang Modern Boarding High School. The data was described related to the kinds of authentic assessment, the implementation, and the problems encountered. The 
observation checklist documented the kinds of authentic assessment implemented by the English teachers. The data was presented as follows:

Table 2. Kinds of Implementing Authentic Assesment by the Teachers

\begin{tabular}{|c|c|c|c|c|c|c|c|c|c|}
\hline \multirow{3}{*}{ Teacher } & \multicolumn{7}{|c|}{ Types of Authentic Assessment } \\
\cline { 2 - 10 } & Port. & Intvw. & Obs. & Wrtg. & Proj. & $\begin{array}{c}\text { Cons. } \\
\text { Res. }\end{array}$ & Perf. & Jour. & $\begin{array}{c}\text { Self- } \\
\text { and } \\
\text { peer- }\end{array}$ \\
\hline A & - & $\sqrt{ }$ & $\sqrt{ }$ & - & $\sqrt{ }$ & $\sqrt{ }$ & $\sqrt{ }$ & - & - \\
\hline B & - & $\sqrt{ }$ & $\sqrt{ }$ & $\sqrt{ }$ & - & $\sqrt{ }$ & $\sqrt{ }$ & - & - \\
\hline
\end{tabular}

The data on the table above was obtained by the documents given by the teachers. The data showed that there were no teacher gave documents related to portfolio, journal and self- and peer assessment. Those documents were not handed out by the teacher while teaching at the time. All the teachers confirmed that they did not implement portfolio because it conducted at the end of the semester. For writing sample, they said that it only conducted on writing skill. Meanwhile, for project, they only did it on productive skill such as speaking and writing. Whereas, there was only one teacher implement writing and project because the teacher $\mathrm{A}$ has no enough time to do this assessment although they know that document was available in students' compulsory book.

The oral interview was conducted by all teachers. They gave a sheet consists of the points that the students can ask about their friend's biography. On interview, the teacher confirmed that the students do interview in pair to ask about their friend biography based on the points that he had wrote on the paper. Observation was assessment implemented by all the teachers in teaching English. The documents were in the form of checklist and rating scale that they used while observing the students. Teacher A used checklist in observing, and the teacher B used rating scale. The categories in their observation sheets were mostly to assess students' attitude. Teachers used observation sheet to assess cognitive and psychomotor aspects. The documents were also confirmed in the interview, they stated that the observation sheets they had were usually used for assessing attitude. Constructed-response items were handed by all teachers, they recorded the students result on a rubric or anecdotal record. The teacher material was also obtained from the internet. So, they asked students to generate the answer on their exercise book. Then, they discussed the answer together, and recorded the student result. Therefore, the kinds of implementing authentic assessment by the teachers were oral interview, observation, writing sample, project, constructed response item and performance. Meanwhile, teachers didn't use portfolio, journal and self and peer-assessment. The data above were related to the each kinds of assessment implemented by teachers, teachers and students' questionnaire, and interview. The diagram below presented the scores of each indicator and the results of using authentic assessments: 
Figure 1. Percentage of Implementing Authentic Assessment by the English Teachers in 2013 English Curriculum

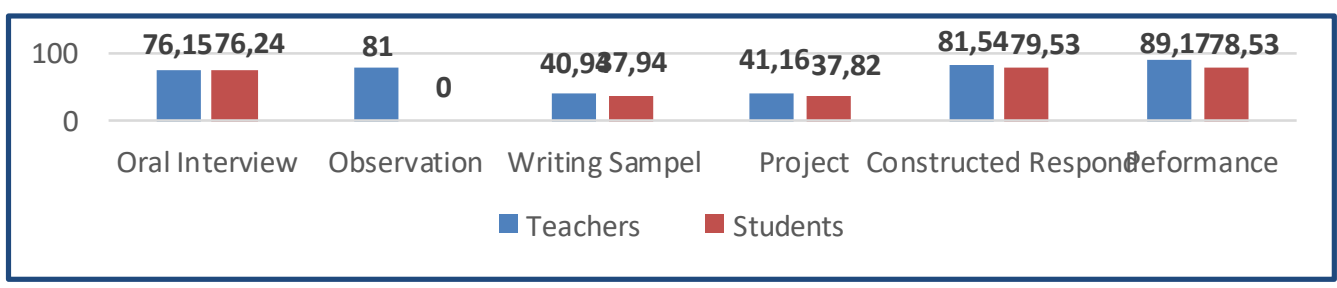

The result of the data was presented as follows: both teachers implemented oral interview in teaching English. The result of teachers' questionnaire showed $76,15 \%$ and students' questionnaire was 76,24 in good category. In interview, they confirmed that before determining to use oral interview and other types of authentic assessment, the teacher identified the standards of the lesson. The standards were developed into indicators which were developed from KI and KD in the syllabus. The students' questionnaire related to the oral interview, it confirmed that the teacher gave the guideline of the interview, and explained the instruction before the students did the interview. The teacher gave feedback in the form of compliment to their activities, the analysis was usually conducted at the end of semester after collecting all the data of student learning result. Based on the findings above, it could be known that the English teachers did the assessment systematically.

For observation, the result on teacher questionnaire showed that teachers obtained $81 \%$ with good category. In interview, She always identified the standard of the lesson before deciding to use observation, and determining the criteria on the rubric she had. She often prepared the rubric, observed the students verbal and non-verbal activities. After that, she analyzed the observation result and reported it to related parties. The result of the observation was analyzed to be used in student report card. Build upon the results of observation, it could be seen that the English teachers had implemented the observation well, although there was a teacher did not do it properly. The implementation of observation by all the teachers was used to assess student attitude toward their lesson. For writing sample, the document given by the teachers related to writing sample was in the form of rating scale and the student work. Teacher B handed over a rating scale that she used to assess student writing sample. She handed over students work in writing. The result on teachers' questionnaire showed 40, 94\% and students' questionnaire 37, 94 with poor category. On interview, teacher B confirmed that they asked the student to describe a person they know by assessing their punctuation and grammar. She also asked the students to write their experience in recount text. The students from teacher B made an application letter and an invitation card. 
Meanwhile, teacher A did not used writing for her assessment since had used it last year and she wanted to vary the assessment she used.

For project assessment, teacher A was the only teacher used project in teaching English. She proved it by giving a piece of paper in the form of rating scale that she used to record student project presentation about present perfect tense. In the paper she did not only assess student skill, but also observed their attitude. The result on teacher questionnaire showed $41,16 \%$ and students' questionnaire 37, 82 with poor category. In interview, she confirmed that she did not assess student knowledge, since she said that knowledge had been integrated to skill. She assessed skill by using the project which was students speaking skill on the presentation. However, the documents from teacher B related to project assessment were not found, because she did not implement it in teaching English. The reason from teacher B was lack of time and not found appropriate material to conduct project assessment in their class.

Both teachers implemented constructed-response item in teaching English. Based on the table above, teachers obtained $81,54 \%$ and students' questionnaire 79,53 which indicated that she is in good category in implementing constructed-response item. In interview, they stated that constructed-response item was similar to reading comprehension. So, they did not design criteria and rubric for this assessment, since they used reading to see whether the students understand or not about the text given. The teachers always prepared a text to be read by the students and sometimes posed high order thinking questions. After the students read the text and answered the question the teacher sometimes gave feedback. When these points would be asked to the teacher, they stated that they was usually used the text on the student compulsory book. The teachers asked high order thinking questions to the students spontaneously while they were discussing the answer, and the students answered it orally.

Documents found for performance-based test were variously. The result on teachers' questionnaire showed that teachers obtained $89,17 \%$ and students' questionnaire 78, 53 with good category. Teacher A handed out the rubrics and used to record students' performance in English. On the rubrics, she wanted to assess the students speaking ability. It could be seen from the criteria they had determined. For example, teacher A assessed student performance by conducting retelling and speech activity. Meanwhile, teacher B gave students learning result of their performance test. She gave a song lyric as a proved that he did performance test. In short, the all teachers used performance-based assessment to assess students' skill in speaking. English Teachers were good in implementing authentic assessment while there were still problems encountered.

Based on interview which was conducted by two teachers, it could be known that teachers still had problem in preparing the authentic assessment. In preparing the authentic assessment, English the teachers need to determine the purpose, choosing the appropriate assessment, design the criteria, and design the rubric of the assessment. These indicators should be implemented by the teachers systematically because they can affect learning process, scoring, and 
reporting. In implementing, the teachers said that she did not know how to make the assessment more authentic. It indicated that she lack of knowledge about authentic assessment. In addition, she also had problem with the limit of time she had in teaching English. As explained in chapter two, the teachers just had two hours per week in teaching English. In scoring, Teachers faced the problem such sometimes postponed observing the students after teaching, because lack of time. Teacher B did not face any significance problems in scoring since they had prepared the rubric to record the student score in learning by using authentic assessment. In reporting, teachers faced the problem in which she had to analyze the result of the data in the form of qualitative report, whereas they found no problem for the quantitative result. The teachers said that they had to describe each student attitude, knowledge, and skill per KD. This description was used by the teachers and school to analyze the student's learning difficulty and their progress. Although this activity was conducted after mid-term test, the teachers said that was complicated.

The assessment is one kind of student's evaluation to see the student learning objective during the learning. The English teachers are demanded to implement the authentic assessment in 2013 English Curriculum. There were some kinds of assessment which has been validated by government (Standar Penilaian Pendidikan, 2013). There are at least nine types of authentic assessment suggested in teaching English namely: portfolio, writing sample, oral interview, performance-based assessment, observation, constructedrespond item, journal, project, and self- and peer-assessment. Based on the nine types of authentic assessment in 2013 English Curriculum which had been proposed by the experts, the teachers had used observation, written test, oral interview, project or exhibition, constructed-respond item, performance-based assessment. Besides, there were some types of authentic assessment did not implemented by the teachers, namely portfolio, journal, and self- and peerassessment because of they could not represent the document that demonstrate them. The real condition shows that some teachers are not familiar enough with some techniques in authentic assessment in teaching English such as self-peer assessment, project based assessment and portfolio (Öz, 2014).

For further discussion, the implementation of each kinds of the assessment which had been implemented by the English teachers would be discussed in this chapter. The English teachers were required to use the authentic assessment in 2013 Curriculum based on the theory derived from (Kemendikbud, 2014). However, the finding showed that on only six kinds of authentic assessment implemented by the teachers. They were oral interview, observation, writing sample, project, constructed-respond item and performance. The first type of authentic assessment called oral interview. In this case, the English teachers asked students to dig more information about their friends based on the guideline given by the teacher. Based on the result obtained from interview and questionnaire, the result on teachers' questionnaire was $76,15 \%$ and it could be included to "good category" on implementing oral interview. The use of oral interview assessment was relevant to the theory and observation checklist 
dealing the action did by English teachers in teaching English. Over all, the teacher had implemented the oral interview assessment well. However, teacher prepared the rubric in the preparation to record the students' show until reporting and analyzing result of oral interview as stated by (Kemendikbud, 2014) and (Mueller, 2017) in indicators no. 5,6,7,8, and 9. The students also confirmed that the teacher did oral interview assessment in teaching, and students also asserted that the teacher implemented the stages stated in their questionnaire well by proving students' questionnaire $76,24 \%$.

The second type of assessment was observation. Based on the result which had been conducted by using interview and questionnaire, the result on teachers' questionnaire were included to "good category" with 81\% implementation of observation. This data was also supported by the instrument and document used by the English teachers to record the students result on observation, which are mostly in the form of rating scale. The percentage indicates that the teachers have been good to implement observation in teaching English and assess the student attitude. The teacher prepared their rubric in to record student attitude in teaching and the teachers viewed the students' attitudes which they wanted to measure on the rubric until the communicating/reporting the analysis result of observation to students, parent, or other teachers as explained by (Kemendikbud, 2014) and (Mueller, 2017).

The third type was writing sample. Based on the result obtained from interview and questionnaire, the result on teacher questionnaire was 40,94\% and could be included to "poor category" on implementing writing sample because of only one teacher conducted this assessment. Over all, the teachers who implemented writing sample had low score. It could be caused by some teacher did not prepare their rubric to record the student writing sample result. Besides, there were some indicators while teaching that the teacher ignored, such as: providing time to conduct self- and peer-assessment, introducing selfassessment gradually to help them identify the good standard of writing, and using 'conference' to ask about student process in writing. The te achers denied the steps in conducting this assessment as suggested by (Kemendikbud, 2014) and (Mueller, 2017). It was also proved by the students' questionnaire result which obtained $37,94 \%$.

The fourth type of authentic assessment was project or exhibition. Based on the result obtained from interview and questionnaire, the result on teacher questionnaire was 41, 16\% and could be included to "poor category" on implementing project although only one teacher used this assessment in teaching English. This result was confirmed in students' questionnaire result 37, $82 \%$ which indicated that the teacher had implemented the project poor while teaching. Actually, another teacher has been successful implementing the assessment in her class. While teaching, the teachers had implemented the assessment completely as the stages suggested by (Majid, 2014; Kemendikbud, 2014; Mueller, 2017) (indicators no. 5,6,7,8, and 9).

The fifth assessment was constructed-response item. Based on the result obtained from interview and questionnaire, the result on teachers' 
questionnaire was $81,54 \%$ and could be included to "good category" on implementing constructed-respond item and all teachers used this assessment in teaching English. The teachers' assessment of constructed-respond items has followed the theory instruction by (Kemendikbud, 2014; Mueller, 2017). The teachers' score were good because in the preparation they designed their rubric. In fact, it influenced their way to score the students. The documents for implementing this assessment were found. Actually, this assessment was very common for the teacher. However, in teaching, the teacher did well. It was also proved by the students' questionnaire result which obtained $79,53 \%$ for preparing a short reading passage or story, posing questions which require high order thinking skill, asking the students to read the text and answer the questions, checking the student work, giving feedback.

The last kind was performance based assessment. This was one of the most popular assessments to be used by the teachers in English language class. Based on the result obtained from interview and questionnaire, the result on teacher questionnaire was $89,17 \%$ and could be included to "good category" on implementing performance-based assessment. All of the English teachers in this research conducted this assessment. The teachers' had prepared their rubric and recorded the student performance well. The teachers' assessment of performance has followed the theory instruction by In teaching, the performances they used to give to the students were retelling activity, speech, and drama. The students' questionnaire showed $78,53 \%$ for the implementation of performance based assessment. Briefly, all of kinds of authentic assessment in 2013 Curriculum had not been conducted yet properly by the teachers with accumulation percentage $45,55 \%$ and included to "poor category".

The teachers still ignored some types of authentic assessment such as portfolio, self- and peer assessment even those assessment stages which was actually crucial for them. In preparation, most of them prepared their rubric. As the consequences, the teacher couldn't record the students score objectively. They couldn't tend to give the student score by starring the student individual effort. It was definitely influence the report which most of them reported and analyzes the result properly.

Using an authentic assessment was uneasy. Teachers could face some handicaps they could find while preparing, implementing, scoring and reporting the assessment (Ellis et al., 2020). According to Kemendikbud (2014) and Mueller (2017), the teacher should identify the standard based on the syllabus on 2013 English curriculum in preparing or designing an authentic assessment. After that, they choose appropriate kinds of authentic assessment to be implemented in teaching based on the standard they have determined, identify the criteria to be assessed in the types of assessment chosen, and create the rubric based on the criteria. In other times, the teacher did not identify the standard based on the syllabus on 2013 English curriculum. Meanwhile, in Standar Penilaian Pendidikan (2013) reported that steps of assessment by reviewing the syllabus as a guideline in creating lesson plan and designing assessment criteria. It could be caused by lack of knowledge and did not want 
to be bothered by administration requirements. So, they tended to use the compulsory book as their standard and most of the assessment they also came from the book. In addition, the teacher also had problem in designing their own rubric. They were difficult to determine the criteria, especially the level of the rubric since it always change overtime. At the same time, teachers select appropriate assessment and develop the instruments and scoring guidelines in accordance with the types chosen. To overcome this problem, the teacher used to use a 'ready-to-use' rubric they got form trainings, although the criteria were not suitable to the standard of the lesson they have identified.

Then, in implementing, the teachers need to know how to manage their class and follow the stages should take to implement their authentic assessment. Whereas, in Standar Penilaian Pendidikan (2013) emphasizes that the teacher begins the lesson by exploring students' learning experience by asking some questions which consider the condition and level of the students. The English teachers couldn't explore students' learning experience because they had no enough time to conduct the authentic assessment while teaching English. They could not finish the activity on authentic as sessment on time. To solve this problem, they tended to do it out of the class. They "steal "time in order all the student could participate and had same opportunities to be involve in the activities. Besides, there was a condition where the students were not serious in doing the assessment, especially for assessment the students did as their homework. There were many plagiarisms found which they got from the internet or copied from their friends in another class. The teachers usually asked the students to recreate the tasks he ordered by using their own idea.

The next stage is scoring. It requires the teachers to assess the students quantitatively and/or qualitatively. The teachers encountered the problem such like subjectivity, especially for observation. Furthermore, the domino effect of not preparing the rubric was also another problem in this stage. Besides, (Standar Penilaian Pendidikan, 2013) argues that the results are reverted feedback to the students in the review form that courage them in learning. To solve these problems, the English teacher score their students by estimating the score based on their subjective view. In scoring, the problem also indicates that the most common instruments they used to record the score were rating scale and subject. So, the English teachers could equip their information related to students result accurately.

The last stage is reporting. As explained by (Kemendikbud, 2014), the English teachers need to analyze the students' scoring result to see their progress during certain period. Then, the results were reported into quantitative and qualitative data to students, parent, or other teachers (including principle) in the schools. The report should be quantitatively and/or qualitatively. In this stage, the problem faced by the teacher was the complexity. Because the reporting is conducted after collecting all the data, so the teachers had to analyze all the data related to the student attitude, knowledge and skill. The English teachers should describe it to analyze the student progress on each score of the three aspects, students and Basic 
Competence (KD). To overcome this problem, the English teacher had the fixedformat in reporting the result which they got from school. The school gave them the soft-copy of the format and formula to analyze the assessment. Build upon the analyses, it could be sum up that the English teachers have implemented authentic assessment and follow the stages they need to take. Nevertheless, the teachers were not maximal yet in implementing the assessment, especially in designing the rubric and scoring. This situation was not missed from their lack of knowledge about authentic assessment and how to manage their classroom and time by implementing authentic assessment.

The finding of this research was the kinds of authentic assessment which were implemented by the English teachers, how they implement it, problems were encountered by them. The kinds of implementing authentic assessment by the teachers were oral interview, observation, writing sample, project, constructed response item and performance. Meanwhile, teachers didn't use portfolio, journal and self and peer-assessment. For oral interview The result of teachers' questionnaire showed 76,15\% and students' questionnaire was 76,24 in good category. For observation, the result on teacher questionnaire showed that teachers obtained $81 \%$ with good category. For writing sample, The result on teachers' questionnaire showed 40, 94\% and students' questionnaire 37, 94 with poor category. For project assessment, the result on teacher questionnaire showed $41,16 \%$ and students' questionnaire 37, 82 with poor category. For constructedresponse item teachers obtained 81,54\% and students' questionnaire 79, 53 which indicated that she is in good category. For performance-based test, teachers obtained 89, 17\% and students' questionnaire 78, 53 with good category. The percentage of using authenctic assessment was $45,55 \%$ with "poor category".

Concerning researches in implementing authentic assessment in 2013 Curriculum, there were several previous researches have been done in different setting which showed the 2013 implementation in schools. The finding Lestari (2010) showed that the English teachers of public junior high school in Malang were still lack of knowledge about authentic assessment. In the implementation, the teachers have no enough preparation in the preparation stage. Consequently the implementation of authentic assessment did not go without a hitch. Finally, the researcher found that the most crucial problem occur in public junior high school in Malang is the limited time in implementing authentic assessment in the classroom. Moreover, the teachers have to teach in a big class. This reason could be main problem all over the teachers in Indonesia. The finding Pemila (2014) reported that the teachers have conducted authentic assessment and follow the stages they need to take. Nevertheless, the teachers didn't implement the assessment maximally yet, especially in designing the rubric and scoring. This situation was not missed from their lack of knowledge about authentic assessment and how to manage their class and time by using authentic assessment.

The implication of this research was for the researchers, teachers and government. For researchers, it can be supporting data to be references to conduct the next research about authentic assssment. For the teachers, it is very 
beneficial recommendation to implement authentic assessment for better way in the classrom. The last for goverment, after more studies conducted in several fields, whether the authentic assessment had been implemented well in schools in Indonesia, the governemnt could measure the succesful of authentic assessment by the teachers and it could be giving the trainings for teachers who still lack of knowledge about authentic assessment

\section{CONCLUSIONS}

Build upon the findings, the results showed the three competences (attitude, knowledge, and skill) has been implemented by using authentic assessment. There were two teachers had implemented observation test to assess student attitude and written test in the form of constructed responseitems to assess their knowledge and oral interview to assess the student's skill. All the English teachers had prepared the assessment while teaching English, score the student quantitatively, and report the result at the end. A teacher did not do it in teaching and there were many indicators on the writing they did not do such as: did not prepare the rubric and record the result. The problems encountered by the English teachers were four stages each in implementing assessment in term of preparing, implementing, scoring, and reporting. The teachers seemed lack of knowledge on some assessment, which could be proved by there was no teacher did some authentic assessments. Besides, they were overburdened by lack of time and class room management. However, the English teachers overcome these problems, the English teacher used to use a 'ready-to-use' rubric they got form trainings in preparing assessment; they tended to do it out of the class in order all students could participate and had same opportunities to be involve in the activities in implementing assessment; The English teachers score their students by estimating the score based on their subjective view in scoring assessment; the English teacher had the fixed-format in reporting the result which they got from school. The school gave them the soft-copy of the format and formula to analyze the assessment in reporting assessment. In conclusion, the implementing authentic assessment in the 2013 curriculum by English teachers was successful enough in several types of assessment and the English teachers was able to overcome the problems happened in the field. But there was still need improvement of 2013 English curriculum by government and English teachers also need to give training in order to understand more widely in authentic assessment and the English teacher should pay attention to the authentic assessment quality for the future. Hopefully, this research could be a reference for next researcher in term of authentic assessment.

\section{ACKNOWLEDGMENTS}

This research was made as part of a series of large-funded research. All research was funded by DRPM funding of Minsiter of Research, Technology, and Higher Education, Republic Indonesia. Expression of thanks is addressed to the ministry of technology research and higher education of the Republic 
Indonesia. For research funding provided under the grant scheme: beginner lecturer research on 2019. Number 007/L10/AL.04/Kontrak-Penelitian/2019. Thank you also expressed to all students at Prof. Dr. Hamka Padang Modern Boarding High School. My research assistatnt and field helper give more contribution and especially for my beloved wife and son for your motivation

\section{AUTHOR CONTRIBUTION STATEMENTS}

This research was conducted by two authors from different colleges. SF was intended to help from the beginning in preparing until the end in reporting of research even NE and WMS as supporting research and supporting of the field more give contribution to collect datas.

\section{REFERENCES}

Adeyemi, B. A. (2015). The Efficacy of Authentic Assessment and Portfolio Assessment in the Learning of Social Studies in Junior Secondary Schools in Osun State, Nigeria. IFE PsychologIA.Google Scholar

Arigusman, A. (2017). Indonesian EFL Learners' Perceptions of Classroom Learning Environments in An EFL Context. ASIAN TEFL: Journal of Language Teaching and Applied Linguistics. https:/ / doi.org/10.21462/asiantefl.v2i2.33

Azim, S., \& Khan, M. (2012). Authentic assessment: An instructional tool to enhance students learning. Academic Research International. Google Scholar

Damayanti, R. S., Suyatna, A., Warsono, W., \& Rosidin, U. (2017). Development of Authentic Assessment instruments for Critical Thinking skills in Global Warming with a Scientific Approach. International Journal of Science and Applied Science: Conference Series. https:// doi.org/10.20961/ijsascs.v2i1.16730

Ellis, C., Haeringen, K. van, Harper, R., Bretag, T., Zucker, I., McBride, S., Rozenberg, P., Newton, P., \& Saddiqui, S. (2020). Does authentic assessment assure academic integrity? Evidence from contract cheating data. Higher Education Research \& Development, 39(3), 454-469. https:/ / doi.org/10.1080/07294360.2019.1680956

Fauziah, R., Abdullah, A. G., \& Hakim, D. L. (2017). Pembelajaran saintifik elektronika dasar berorientasi pembelajaran berbasis masalah. Innovation of Vocational Technology Education. https:/ / doi.org/10.17509/invotec.v9i2.4878

Haslina, Y. (2017). Kinerja Guru Dalam Implementasi Kurikulum 2013 Pada Sma Negeri 5 Lhokseumawe. Jurnal Administrasi Pendidikan: Program Pascasarjana Unsyiah, $5(4)$. http:// www.jurnal.unsyiah.ac.id/JAP/article/view/9359

Idham, F. I., Nadrun, D. (2015). The Use of Authentic Assessment in English Writing Skill to the Eleventh Grade Students. e-Journal of English Language Teaching Society (ELTS). Google Scholar 
Kemendikbud. (2014). Peraturan Menteri Pendidikan Dan Kebudayaan Republik Indonesia Nomor 103 Tahun 2014 Tentang Pembelajaran Pada Pendidikan Dasar Dan Pendidikan Menengah. Pedoman Evaluasi Kurikulum. https:/ / doi.org/10.1017/CBO9781107415324.004

Kinay, I., \& Bagceci, B. (2016). The Investigation of the Effects of Authentic Assessment Approach on Prospective Teachers' Problem-Solving Skills. International Education Studies. https:// doi.org/10.5539/ies.v9n8p51

Kunandar. (2013). Penilaian Autentik (Penilaian Hasil Belajar Peserta Didik Berdasarkan Kurikulum 2013). PT. Raja Grafindo Persada. Google Scholar

Kurinasih, I. dan B. S. (B). (2014). Implementasi Kurikulum 2013 Konsep dan Penerapan. Kata Pena. Google Scholar

Lestari, N. A. (2010). A Survey on the Implementation of Authentic Assessment in Public Junior High Schools in Malang Municipality. Universitas Negeri Malang. Google Scholar

Maba, W., \& Mantra, I. B. N. (2018). The primary school teachers' competence in implementing the 2013 curriculum. SHS Web of Conferences. https:/ / doi.org/10.1051/shsconf/20184200035

Majid, A. (2014). Implementasi kurikulum 2013: kajian teoretis dan praktis. Interes Media. Google Scholar

Martinez Lirola, M., \& Irwin, D. S. (2016). Challenges in the Application of Genre Theory to Improve L2 Academic Writing: Effective Reports and Assessment. ASIAN TEFL Journal of Language Teaching and Applied Linguistics. https:// doi.org/10.21462/asiantefl.v1i1.4

Merriam, S. B., \& Grenier, R. S. (2019). Qualitative Research in Practice: Examples for Discussion and Analysis. John Wiley \& Sons. Google Scholar

Moser, A., \& Korstjens, I. (2018). Series: Practical guidance to qualitative research. Part 3: Sampling, data collection and analysis. European Journal of General Practice, 24(1), 9-18. https:/ / doi.org/10.1080/13814788.2017.1375091

Mueller, J. (2017). Authentic Assessment Toolbox. 2017.

Öz, H. (2014). Turkish teachers' practices of Assessment for learning in the English as a foreign language classroom. Journal of Language Teaching and Research. https:/ / doi.org/10.4304/jltr.5.4.775-785

Pemila, W. A. (2014). The Implementation of Authentic Assessment in Teaching Bahasa Indonesia for Senior High Schools Based on 2013 Curriculum in Gunungkidul District. Universitas Negeri Yogyakarta. Google Scholar

Standar Penilaian Pendidikan, Permendikbud RI No. 66 (2013). Google Scholar

Rukmini, D., \& Saputri, L. A. D. E. (2017). The authentic assessment to measure students'english productive skills based on 2013 curriculum. Indonesian Journal of Applied Linguistics, 7(2), 263-273. https:/ / doi.org/10.17509/ijal.v7i2.8128

Retnawati, H., Hadi, S., \& Nugraha, A. C. (2016). Vocational high school teachers' difficulties in implementing the assessment in curriculum 2013 in Yogyakarta Province of Indonesia. International Journal of Instruction. https:/ / doi.org/10.12973/iji.2016.914a 
Setiadi, H. (2016). Pelaksanaan penilaian pada Kurikulum 2013. Jurnal Penelitian Dan Evaluasi Pendidikan, 20(2), 166-178. https:/ / doi.org/10.21831/ pep.v20i2.7173

Widowati, A., Nurohman, S., \& Anjarsari, P. (2017). Developing science learning material with authentic inquiry learning approach to improve problem solving and scientific attitude. Jurnal Pendidikan IPA Indonesia. https:// doi.org/10.15294/jpii.v6i1.4851

Yusuf, A. M. (2017). Asesmen dan evaluasi pendidikan. Prenada Media. Google Scholar

Zulela, M. S., \& Marini, A. (2019). Sosialisasi Penilaian Autentik dalam Kurikulum 2013 pada Guru Sekolah Dasar. Prosiding Pengabdian, 1(1), 110. Google Scholar

Copyright Holder :

(c) Atmarizon, D., Efendi, N., \& Franchisca, S. (2020)

First Publication Right :

(C) Jurnal Iqra' : Kajian Ilmu Pendidikan

This article is under:

(1) (1) (2) 